\title{
ANALISIS PENGEMBANGAN SUMBER BELAJAR DIGITAL MEDIA VIDEO UNTUK MENINGKATKAN MUTU SDM GURU MELALUI PEMANFAATAN TEKNOLOGI PADA PEMBELAJARAN TATAP MUKA DI ERA NEW NORMAL
}

\author{
${ }^{1}$ Vitry Marenden, ${ }^{2}$ Witarsa Tambunan, ${ }^{3}$ Mesta Limbong \\ 1,2,3 Magister Administrasi Pendidikan PPs-UKI, Jakarta, Indonesia \\ e-mail: witarsa.oke@gmail.com, mesta.limbong@uki.ac.id
}

\begin{tabular}{l|l|l} 
Received : April, 2021 & Accepted : Mei, 2021 & Published : Juli, 2021
\end{tabular}

\begin{abstract}
The purpose of this study was to determine: Analysis of the Development of Digital Media Video Learning Resources. To improve the quality of teacher human resources through the use of technology in face-to-face learning in the new normal era. To ensure the quality of face-to-face learning that is more meaningful for students in the new normal era. This analysis involves the entire population (Nonprobability Sampling). The total population in this study were 61 teachers and 32 students of class VIII. 1 students of SMPN 2 Rantepao. The quality of human resources of SMPN 2 Rantepao teachers through the use of technology is quite good in utilizing technology as a source of information, learning resources and as an evaluation tool for TCR learning outcomes, respectively, which are $73.44 \%$, $74.42 \%$ and $72.13 \%$ as well as teachers SMPN 2 Rantepao is quite good at using digital video learning resources as an alternative teaching material in the learning process with a TCR of $75.30 \%$. The results of the analysis of class VIII.1 students of SMPN 2 Rantepao show that the use of Digital Media Video Learning Resources is high in realizing effective learning situations for students with a TCR of $82.25 \%$ in face-to-face learning in the new normal era. However, the teachers of SMPN 2 Rantepao are still not good at using technology as a learning medium with a TCR of $63.93 \%$ and designing digital learning resources for video media to make it easier for teachers to carry out learning with a TCR of $63.60 \%$.
\end{abstract}

Keywords: digital learning resources, video media, the quality of teacher human resources, the new normal era

\footnotetext{
Abstrak

Tujuan penelitian ini untuk mengetahui: Analisis Pengembangan Sumber Belajar Digital Media Video . Untuk Meningkatkan Mutu SDM Guru Melalui Pemanfaatan Teknologi pada Pembelajaran Tatap Muka di Era New Normal. Untuk menjamin kualitas pembelajaran tatap muka yang lebih bermakna bagi peserta didik di era new normal.Analisis ini melibatkan seluruh populasi (Nonprobability Sampling). Jumlah populasi dalam penelitian ini adalah 61 Guru dan 32 siswa kelas VIII.1 siswa SMPN 2 Rantepao. Mutu SDM Guru SMPN 2 Rantepao melalui Pemanfaatan Teknologi cukup baik dalam memanfaatkan teknologi sebagai sumber informasi, sumber belajar dan sebagai alat evaluasi hasil belajar TCR masing - masing adalah 73,44\%,74,42\% dan 72,13\% dan juga guru - guru SMPN 2 Rantepao sudah cukup baik dalam menggunakan sumber belajar digital media video sebagai alternatif bahan ajar dalam proses pembelajaran dengan TCR 75,30\%.
} 
Hasil analisis siswa kelas VIII.1 SMPN 2 Rantepao menunjukkan bahwa ternyata Penggunaan Sumber Belajar Digital Media Video tinggi dalam mewujudkan situasi belajar efektif kepada siswa dengan TCR $82,25 \%$ pada pembelajaran tatap muka di era new normal. Namun guru - guru SMPN 2 Rantepao masih kurang baik dalam memanfaatkan teknologi sebagai media pembelajaran dengan TCR sebesar 63,93\% dan merancang sumber belajar digital media video untuk memudahkan guru dalam melaksanakan pembelajaran dengan TCR 63,60\%.

Kata Kunci: sumber belajar digital, media video, mutu sdm guru, era new normal

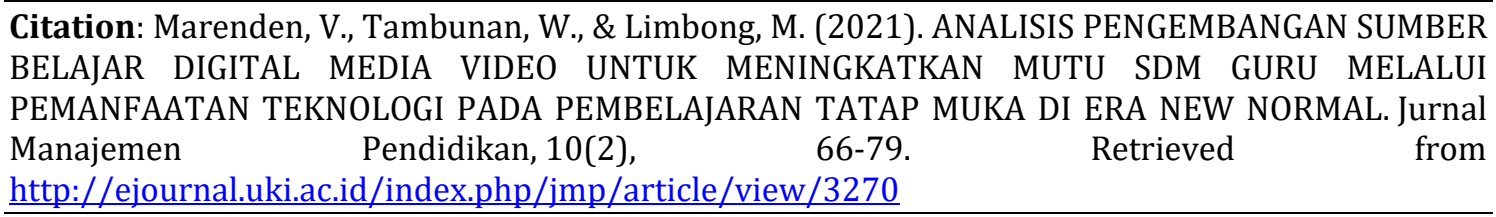

\section{PENDAHULUAN}

Covid -19 (Coronavirus disease 2019) mempengaruhi sebagian besar aspek hidup manusia $($ Adam,2020) tanpa terkecuali pada aspek pendidikan khususnya di Indonesia. Pemerintahpun dengan cepat meresponi dampak tersebut di masa pandemi salah satunya dengan merilis buku panduan "Penyelenggaraan Pembelajaran Pada Tahun Pelajaran dan Tahun Akademik 2020/2021 Dimasa Pandemi Coronavirus Disease (Covid-19)" oleh keputusan bersama 4 (empat) Mentri diantaranya Mentri Pendidikan dan Kebudayaan, Mentri Agama, Mentri Kesehatan dan Mentri Dalam Negeri pada tanggal 30 Juni 2020. Kegiatan pada proses pembelajaran di Indonesia pada masa pandemi COVID-19 sejauh ini dilakukan secara daring. Dan dalam pengimplementasiannya ternyata masih perlu beberapa adaptasi serta perbaikan. Berdasarkan kualitas faktor-faktor pendukung pelaksanaan proses pembelajaran, faktor pendukung tersebut diantaranya adalah gawai, komputer, koneksi internet, serta televisi (Putria dkk, 2020).

Dalam praktiknya, kegiatan belajar mengajar secara daring di Indonesia dapat dikatakan belum siap. Hal tersebut didasari oleh kualitas elemen pendukung dalam pelaksanaan pembelajaran daring di Indonesia masih dapat dikatakan cukup rendah. Selain itu, proses pelaksanaan pembelajaran daring di Indonesia belum memiliki acuan tetap (dalam hal ini kurikulum pembelajaran daring). Selanjutnya, kualitas faktor pendukung proses pembelajaran secara daring Indonesia juga masih belum merata. Apabila penggunaan metode daring masih diteruskan sementara kualitas faktor pendukung yang masih rendah, maka kualitas luaran proses pendidikan (dalam hal ini kompetensi lulusan) akan terus menurun. (Aspiyana dan Rianit, 2020: 62). Saat ini pemerintah menerapkan kebijakan New Normal atau biasa juga disebut dengan "adaptasi kebiasaan baru" termasuk disektor pendidikan. ada kebijakan adaptasi kebiasaan baru, kita sebagai masyarakat diberikan kebebasan untuk beraktifitas dan bekerja seperti biasa namun harus memperhatikan seluruh aspek protokol kesehatan termasuk membuka kembali sekolah untuk melakukan proses pembelajaran secara tatap muka.

Berdasarkan analisis kondisi proses pembelajaran di Indonesia, pemerintah melalui SKB (Surat Keputusan Bersama) nomor 03 tahun 2020 menimbang untuk melaksanakan proses pembelajaran tatap muka pada awal tahun 2021 semester genap tahun pelajaran 2020/2021. Menteri Pendidikan dan Kebudayaan, Menteri Agama, Menteri Kesehatan, dan Menteri Dalam Negeri Republik Indonesia, 2020). Oleh karena itu, pemerintah dengan masyarakat harus mempersiapkan diri dan lingkungan sekitarnya pada pelaksanaan pembelajaran tatap muka yang rencananya akan mulai dilaksanakan pada semester genap tahun pelajaran 2020/2021. Kebijakan membuka sekolah untuk melakukan proses pembelajaran secara tatap muka dikemukakan oleh Kementrian Pendidikan dan Kebudayaan karena dengan sistem pembelajaran jarak jauh secara daring maupun luring dianggap 
banyak kelemahan sehingga kurang ideal dan kemudian pembelajaran tatap muka tersebut dilaksanakan serempak pada semester genap 2020/2021.

SMPN 2 Rantepao adalah salah satu sekolah Negeri di Kabupaten Toraja Utara, Sulawesi selatan yang telah melaksanakan proses pembelajaran secara tatap muka di era new normal sejak awal tahun 2021 semester genap tahun pelajaran 2020/2021. Untuk menjamin kualitas pendidikan, di era new normal kesehatan dan keselamatan stake holder SMPN 2 Rantepao harus diutamakan dan pendidikan yang tidak boleh dihentikan. Untuk itu kita perlu duduk bersama guna merumuskan solusi ideal untuk dunia pendidikan di era new normal mengakomodasi peran guru, sekolah dan orang tua dalam proses pendidikan siswa (Maemunnah dkk,2021:76). Ketercapaian mutu atau kualitas SMPN 2 Rantepao dapat dilihat dari mutu SDM Guru dilihat dari beberapa dimensi esensial yang dihasilkan dan saling berkaitan, yaitu Input, Proses, Output. Saat ini, di masa new normal setiap satuan pendidikan tetap harus mampu menjamin dimensi esensial tersebut terutama dalam menjamin kualitas proses dan output. SMPN 2 Rantepao harus memiliki standar melalui inovasi sumber pembelajaran agar kualitas pembelajaran terjamin kualitasnya. Dibutuhkan peran serta seluruh individu di SMPN 2 Rantepao agar mampu menjamin kualitas pembelajaran yang berkualitas. Salah satu upaya yang dilakukan (Anriani, Hidayat \& Setiani (2020 : 391) adalah meningkatkan mutu SDM guru, dengan memanfaatkan teknologi untuk membuat media video sebagai sumber belajar digital dalam proses pembelajaran untuk meningkatkan kualitas dari proses pembelajaran, melalui pengembangan sumber belajar digital yang tentu saja membutuhkan kebijakan dan strategi yang tepat agar pembelajaran terjamin kualitasnya pada pelaksanaan kembali proses pembelajaran secara tatap muka di era new normal.

Menurut Prensky seorang tokoh inovasi pendidikan menyatakan bahwa Digital native adalah generasi yang tumbuh dan dibesarkan di tengah dunia teknologi digital. Digital native adalah sebutan bagi generasi yang sedari lahir sudah terbiasa hidup dan dikelilingi oleh teknologi sebagai alat bantu dalam aktivitas kehidupannya sehari-hari (Christina, 2016). Sumber belajar merupakan sumber informasi yang disajikan dan disimpan dalam berbagai bentuk media, yang dapat membantu dalam proses pembelajaran. Paradigma pendidikan tatap muka di era new normal memberikan suatu hal yang baru bagi para pelaku pendidikan. New normal menjadikan proses pendidikan harus beradaptasi dengan segala perubahan yang terjadi baik kualitas maupun kuantitanya (Zuraini \& Nurhayati, 2021). Pelaku pendidikan pada pelaksanaan kembali proses pembelajaran secara tatap muka di era new normal. Media diperlukan untuk lebih memperjelas materi ajar atau bahan ajar yang akan disampaikan guru kepada peserta didik. Lebih tepat media yang digunakan oleh guru maka semakin tinggi tingkat keberhasilan guru dalam proses pembelajaran sehingga akan menghasilkan siswa yang berprestasi. Pemanfaatan teknologi dalam pembelajaran tatap muka menjadi modal utama dalam keberhasilan suatu proses pembelajaran di era new normal (Nurhayati \& Zuhra, 2020). Media pembelajaran juga merupakan alat atau sumber belajar yang dapat membantu seorang guru dalam menyampaikan pesan kepada siswa.Hal ini dikarenakan teknologi digital sebagai media menjadi pusat pembelajaran sehingga dapat menjadikan proses pembelajaran berjalan dengan baik.

Selanjutnya, guru juga harus mampu mendesain bahan ajar semenarik mungkin dan memanfaatkan berbagai media teknologi digital sebagai penunjang dalam melakukan proses pembelajaran tatap muka di era new normal. Dipilihnya sumber belajar video dibandingkan dengan sumber belajar lain atau media pembelajaran lain dalam kegiatan belajar pembelajaran dikarenakan keunggulan sumber belajar video tersebut, yaitu dapat menjembatani keterbatasan pengalaman siswa terhadap objek yang langkahnya terlalu cepat atau lambat, serta memberikan pengalaman nyata kepada siswa, memicu keterlibatan siswa secara aktif dalam pembelajaran, mendorong munculnya pola pembelajaran yang bervariasi, dan sekaligus membuat pesan yang disampaikan sulit dilupakan oleh siswa. Adanya media pembelajaran di sekolah membantu dalam pelaksanaan proses belajar mengajar. Pemanfaatan media pembelajaran dalam proses pembelajaran juga perlu direncanakan dan dirancang secara sistematis agar media pembelajaran efektif untuk digunakan. Salah satu media teknologi informasi dan komunikasi yang mampu menjangkau dan paling populer di kalangan masyarakat luas adalah media video. 
Video juga merupakan media elektronik yang mampu menggabungkan teknologi audio dan visual secara bersama sehingga menghasilkan suatu tayangan yang dinamis dan menarik. Dengan adanya dua unsur tersebut diharapkan siswa mampu menerima, memahami, dan mengingat pesan pembelajaran. Media audio visual memiliki fungsi (1) memperjelas penyajian pesan agar tidak terlalu bersifat verbalistis, (2) mengatasi keterbatasan ruang, waktu dan daya indra, (3) penggunaan media pendidikan secara tepat dan bervariasi dapat mengatasi sifat pasif anak didi Pemanfaatan media pembelajaran yang tepat dalam proses belajar dan mengajar di kelas dapat membawa keberhasilan bagi guru maupun siswa. Selain itu peran guru sangatlah penting di dalam proses pembelajaran, guru juga dituntut untuk bisa membuat media yang kreatif dan inovatif serta dapat memanfaatkan media pembelajaran yang tersedia di sekolah. Video pembelajaran merupakan sarana alternatif dalam melakukan proses pembelajaran berbasis teknologi dalam mengoptimalkan proses pembelajaran. Video pembelajaran memiliki peranan yaitu dapat menyampaikan materi pelajaran yang lebih menarik, termasuk visualisasi materi, sehingga lebih menarik dalam proses pembelajaran dan sangat sesuai pada pelaksanaan kembali proses pembelajaran secara tatap muka di era new normal.

Guna menjawab tantangan di era globalisasi saat ini menuntut sumber daya manusia (SDM) yang berkualitas dan unggul, saat ini perkembangan ilmu pengetahuan dan teknologi (IPTEK) sudah semakin maju sehingga guru SMPN 2 Rantepao harus dapat memiliki kemampuan untuk berpikir kritis dan kreatif agar dapat memecahkan tantangan global dan salah satu keseharusan yang dilakukan oleh sekolah adalah meningkatan sumber daya manusianya dalam hal ini guru sebagai SDM yang berprestasi dibidangnya pada pelaksanaan kembali proses pembelajaran secara tatap muka di era new normal. Tidak ada pilihan selain mengembangkan Sumber Daya Manusia (SDM) yang berkualitas dan efektif. Mereka harus memiliki kemampuan dan kemauan berkolaborasi untuk mempengaruhi kualitas pembelajaran yang dilakukan dengan cerdas dan berkompeten, memiliki keterampilan serta kreativitas dalam mengembangkan sumber belajar digital belajar melalui media video pada pembelajaran tatap muka di era new normal karena media pembelajaran yang baik (Mukarromah \& Siskawati (2020 : 41) adalah media yang mengikuti perkembangan zaman dan teknologi untuk menjamin kualitas pembelajaran tentu dibutuhkan kreatifitas dan inovasi guru untuk merencanakan dan menerapkan strategi dan model pembelajaran yang tepat serta media sebagai salah satu sumber pembelajaran tatap muka di era new normal. Kreativitas guru dalam mengembangkan media video sebagai sumber belajar digital merupakan faktor yang sangat memengaruhi pembelajaran di sekolah. (Ozkeser, 2019).

Pengembangan media video sebagai sumber belajar digital merupakan salah satu cara yang dapat meningkatkan mutu SDM Guru SMPN 2 Rantepao dalam menghadapi pelaksanaan kembali proses pembelajaran secara tatap muka di era new normal. karena penerapan sistem yang baru terkadang menjadi kendala tersendiri bagi sekolah untuk melakukan implementasi proses pembelajaran hal ini terkait dengan SDM yang belum mampu mengikuti perkembangan IPTEK (Nasrika,2019) terutama dalam mengembangkan sumber belajar. Karena inovasi sumber belajar akan merubah sistem pembelajaran tatap muka di era new normal dari yang kurang maksimal ke arah yang lebih baik dirancang untuk memungkinkan terjadinya proses belajar pada siswa SMPN 2 Rantepao yang dikelola secara kreatif, dinamis, dengan menerapkan pendekatan multi untuk menciptakan suasana dan proses pembelajaran yang kondusif bagi siswa. Perkembangan IPTEK di bidang pendidikan yang mengharuskan guru di SMPN 2 Rantepao mengikuti perubahan tersebut akan tetapi guru sebagai SDM terpenting dalam kegiatan belajar-mengajar di SMPN 2 Rantepao pada proses pembelajaran secara tatap muka yang mengacu pada era new normal dipandu dengan mengikuti protokol kesehatan masih belum bisa secara optimal dalam mengikutinya (Bahri \& Arafah,2020:21). Itulah sebabnya melalui kajian literatur penulis berusaha untuk mencoba memberi pemaparan hasil analisis tentang "Pengembangan Sumber Belajar Digital Media Video Untuk Meningkatkan Mutu SDM Guru Melalui Pemanfaatan Teknologi pada Pembelajaran Tatap Muka di Era New Normal".

(SDM) Guru Pembelajaran di Era New Normal

Manajemen Sumber Daya Manusia diartikan oleh sebagai suatu pengolahan dan pendayagunaan sumber daya yang ada pada individu. Dalam arti lain merupakan suatu perencanaan, 
pengorganisasian, pelaksanaan pengawasan terhadap pengadaan, pengembangan, pemberian balas jasa, pengintegrasian, pemeliharaan dan pemisahaan tenaga kerja dalam rangka mencapai tujuan suatu lembaga. Manajemen sumber daya manusia di setiap lembaga/organisasi haruslah sesuai dengan tujuan organisasi dengan tidak berlebihan ataupun tidak terlalu kurang. Sebab, adanya suatu kelebihan atau kekurangan penerapan sasaran di masing-masing unit lembaga menunjukkan adanya wasted atau pemborosan penggunaan sumber daya manusia. Maka dari itu setiap unit lembaga yang mengelola atau menggunakan sumber daya manusia harus mampu menjaga keseimbangan yang tepat antara kualitas dan kuantitas sumber dayanya masing - masing. Agar selaras dengan tujuan yang telah ditetapkan. Karena itu sekolah sebagai salah satu lembaga pendidikan perlu dan utama di manajemen dalam hal ini ialah komponen SDM, yaitu guru sebagai tenaga pendidik dan lembaga pendidikan harus terus ontimis dan gencar untuk melakukan sosialisasi dan aktivitas yang saling berkaitan untuk keoptimalan tujuan yang dicapai (Setiana, 2018). Sebagai bagian penentu dominan kualitas pendidikan, guru haruslah bermutu dan berkinerja baik dalam globalisasi dengan barusaha menguasai berbagai teknologi informasi dan komunikasi. Sebab, teknologi mengalami perubahan yang dahsyat dalam era globalisasi. Dalam sistem pendidikan nasional guru memiliki peranan strategis pada proses pembelajaran secara khusus dan proses pendidikan secara keseluruhan.

Secara umum keberhasilan usaha seseorang mempunyai hubungan yang erat dengan kualitas manusia yang melakukan usaha atau tugas tersebut. Kualitas sumber daya manusia SDM) yang nampak melalui kompetensi yang dimilikinya menjadi hal esensial untuk menjadi manusia professional. Begitupum dengan keberhasilan suatu sekolah. Keberhasilan sekolah sangat ditentukan oleh keberhasilan pimpinannya mengelola tenaga kependidikan yang tersedia di sekolah. Pengelolaan atau manajemen tenaga kependidikan bertujuan untuk memberdayagunakan tenaga kependidikan secara efektif dan efisien untuk mencapai hasil yang optimal, namun tetap dalam kondisi yang menyenangkan. Oleh sebab itu, kepala sekolah sebagai seorang pemimpin harus mampu mengolah dan memanfaatkan SDM guru di sekolah, sehingga tercapai efektivitas sekolah yang pada ujungnya menghasilkan perubahan yang diharapkan pada anak didik. Manajemen sumber daya manusia bukanlah suatu tujuan dan akhir suatu proses, melainkan suatu perangkat atau alat untuk membantu tercapainya suatu tujuan secara keseluruhan. Sumber daya manusia (SDM) dalam dunia pendidikan sangatlah penting dan menjadi hal utama yang harus mendapat perhatian khusus dari semua pemegang kebijakan.

Haji S, (2019) berpendapat bahwa jika mutu pendidikan ingin mencapai pada tingkat pencapaian terbaik maka sumber daya manusia (SDM) harus ditingkatkan. Sumber daya manusia (SDM) sangat berperan dalam menentukan kemajuan suatu negara. Guru sebagai SDM di sekolah merupakan tenaga profesional yang akan bertugas merencanakan dan melaksanakan proses pembelajaran, menilai pembelajaran karena itu perlu mengikuti program pembimbingan, pelatihan serta pengembangan untuk meningkatkan kualitasnya dalam melaksanakan proses pembelajaran yang dilaksanakan secara tatap muka di era new normal. Menurut Yuwono,dkk (2020), Salah satu faktor yang amat menentukan dalam upaya meningkatkan kualitas SDM melalui Pendidikan adalah tenaga Pendidik (Guru), dimana Guru merupakan tokoh utama dalam peran peningkatan SDM Indonesia unggul. Ketokohan guru dapat dilihat pada peran strategisnya di kelas yang setiap hari berhadapan dengan siswa atau peserta didik pada kegiatan belajar mengajar. Guru yang mampu memanfaatan teknologi sebagai media mengembangkan inovasi sumber belajar dalam menyajikan materi pada KBM (kegiatan belajar mengajar) akan menjadikan peserta didik mudah dan cepat menyerap materi pembelajaran yang disajikan. Sebaliknya, guru yang kurang cakap dalam memanfaatkan teknologi akan menjadikan peserta didik kesulitan memahami materi pelajaran yang disajikannya di era globalisasi. Jadi, meningkatkan SDM (sumber daya manusia) Guru akan mempengaruhi kualitas pendidikan di Indonesia. Guru bukan saja menjadi faktor penting dan strategis bagi peningkatan kualitas pendidikan, betapa keberadaan guru menjadi kunci bagi keberhasilan pendidikan anak-anak di sekolah. Karena itu paradigma, sikap, tindakan dan kebiasaan guru dalam mengelola pembelajaran adalah hal mendasar yang penting untuk diperhatikan.

Menurut Henry Simamora (2018), sumber daya manusia (SDM) merupakan pendayagunaan, pengembangan, penilaian, pemberian balas jasa, dan pengelolaan individu anggota organisasi atau kelompok pekerja. Input pendidikan adalah segala sesuatu yang harus tersedia karena dibutuhkan 
untuk berlangsungnya proses. Proses pendidikan merupakan berubahnya sesuatu menjadi sesuatu yang lain dengan mengintegrasikan input sekolah sehingga mampu menciptakan situasi pembelajaran yang menyenangkan, motivasi dan minat belajar yang tinggi. Output pendidikan merupakan kinerja sekolah yang dapat diukur dari kualitasnya, produktivitasnya, efisiensinya, inovasinya, dan moral kerjanya. Dalam konsep yang lebih luas, mutu pendidikan mempunyai makna sebagai suatu kadar proses dan hasil pendidikan secara keseluruhan yang ditetapkan sesuai dengan pendekatan dan kriteria tertentu. Meningkatkan mutu SDM Guru melalui IPTEK akan meningkatkan mutu SDM guru Indonesia. Dengan memanfaatkan teknologi di era globalisasi, tertama dalam pemanfaatannya sebagai media pembelajaran dalam pengembangan inovasi sumber belajar untuk menjamin kualitas pembelajaran tatap muka yang lebih bermakna bagi peserta didik di era new normal.

\section{Pemanfaatan Teknologi pada Pembelajaran Tatap Muka di Era New Normal}

Perkembangan teknologi informasi dan komunikasi (TIK) saat ini memiliki pengaruh yang sangat besar dalam segala aspek kehidupan termasuk dunia pendidikan. Dunia pendidikan diharapkan untuk menyesuaikan perkembangan tersebut sebagai usaha dalam meningkatkan mutu SDM Guru. Seiring dengan perkembangan zaman dan kemajuan teknologi informasi dan komunikasi, guru tidak hanya menyampaikan materi pembelajaran secara konvensional saja tetapi guru dituntut mampu mengikuti perkembangan zaman untuk mendukung proses pembelajaran yang lebih maksimal yaitu seperti penggunaan teknologi informasi dan komunikasi sebagai pendukung proses pembelajaran. Sejalan dengan Peraturan Pemerintah Republik Indonesia Nomor 74 Tahun 2008 pasal 3 yaitu guru dituntut mampu memanfaatkan teknologi informasi dan komunikasi dalam proses pembelajaran. Dengan perataruran pemerintah tersebut menghimbau kepada guru untuk memanfatkan teknologi informasi dan komunikasi dalam proses pembelajaran karena teknologi informasi dan komunikasi memiliki banyak kelebihan Banyak kelebihan yang dimiliki teknologi informasi dan komunikasi dalam proses pembelajaran, teknologi informasi dan komunikasi memudahkan peserta didik mengakses informasi digital secara efisien dan efektif (Fanny, 2020:68). Efisien dalam hal ini penggunaan teknologi informasi dan komunikasi untuk mencari informasi lebih murah dan terjangkau sedangkan efektif karena penggunaannya dalam mencari informasi yang dibutuhkan lebih cepat. Sejalan dengan Asra (2020:492) dalam (Lamambar,2021) menyatakan bahwa "Teknologi informasi dan komunikasi membuat pembelajaran lebih menarik dan interaktif". Pembelajaran yang menarik tentu membuat minat peserta didik dalam proses pembelajaran meningkat sehingga terjadi interaksi yang baik antar peserta didik dan guru. Pembelajaran menggunakan teknologi informasi dan komunikasi diharapkan mampu meningkatkan hasil belajara peserta didik baik pada aspek kognitif maupun psikomotor.

Teknologi informasi dan komunikasi memiliki pengaruh yang besar dalam pendidikan termasuk pada pembelajaran tatap muka di era new normal. Perubahan tatanan gaya hidup merupakan sebuah upaya yang dilakukan Indonesia untuk melakukan adaptasi pada masa pandemi yang disebut dengan era new normal (Saputra dan Muhrammah, 2020:75) dalam (Lamambar,2021). Era new normal merupakan proses perubahan yang sangat cepat sehingga sistem dan kurikulum pendidikan di Indonesia harus di upgrade (Rahman dan Bhakti, 2020:38). Salah satu perubahan pendidikan di era new normal adalah penggunaan TIK yaitu penggunaan komputer dan smartphone (Suprijono dkk, 2020). Berdasarkan uraian mengenai pembelajaran berbasis teknologi, informasi dan komunikasi dapat disimpulkan bahwa proses pembelajaran yang menggunakan teknologi informasi dan komunikasi sebagai alat bantu untuk menyampaikan materi pembelajaran yang abstrak menjadi nyata dengan mengilustrasikan berbagai fenomena, sehingga di dalam proses pembelajaran guru tidak hanya beracuan terhadap buku saja, tetapi juga mengembangkan pembelajaran sesuai dengan karakteristik peserta didik dan mampu mengikuti perkembangan zaman, serta mengoptimalkan segala kemampuan guru untuk mendukung keberhasilan pembelajaran.

Kondisi demikian menuntut lembaga pendidikan untuk melakukan inovasi dalam proses pembelajaran. Inovasi pembelajaran tersebut ialah dengan melakukan pembelajaran yang memanfaatkan teknologi digital pada pembelajaran tatap muka di era new normal."Pembelajaran berbasis teknologi informasi dan komunikasi merupakan pembelajaran yang tidak hanya 
mencangkup membelajarkan kepada peserta didik menggunakan media buku" (Khairi dan Danil, 2015:131). Seharusnya guru mampu mengolah, menyajikan pembelajaran dengan memanfaatkan kecanggihan teknologi, informasi dan komunikasi yang menjadikan materi didesain semenarik mungkin sehingga dapat meningkatkan rasa ingin tahu peserta didik, hal ini menjadikan motivasi dan minat belajar peserta didik meningkat. Peningkatan minat dan motivasi belajar peserta didik diharapkan mampu meningkatkan hasil belajar peserta didik. Guru memulai pembelajaran tatap muka di era new normal untuk membangun kreativitasitas, mengasah keterampilan siswa, serta meningkatkan kualitas diri dengan adanya sistem perubahan ini, bagaimana cara pandang dan pola interaksi kita dengan teknologi yang sekarang sudah berkembang pesat. Perkembangan teknologi informasi beberapa tahun belakangan ini berkembang dengan pesat, sehingga dengan adanya perkembangan ini telah mengubah paradigma pendidikan dalam mencari serta mendapatkan informasi, yang tak lagi terbatas pada sebuah informasi surat kabar, audio visual maupun elektronik, tetapi juga sumber-sumber informasi lainnya seperti melalui jaringan Internet.

Salah satu bidang yang mendapatkan dampaknya dengan perkembangan teknologi ini ialah bidang pendidikan, yang mana pada dasarnya pendidikan adalah suatu proses komunikasi dengan informasi dari guru kepada siswa yang berisikan informasi-informasi mengenai pendidikan, yang memiliki unsur-unsur pendidik sebagai sumber informasi, media sebagai sarana penyajian ide, gagasan dan materi pendidikan serta peserta didik itu sendiri, beberapa bagian unsur ini bersinggungan dengan media teknologi digital. Untuk mengatasi permasalahan yang berkaitan dengan dunia pendidikan memulai pembelajaran secara tatap muka di era new normal ini dapat dilakukan dengan cara memanfaatkan teknologi informasi didalam bidang pendidikan. Dengan adanya pemanfaatan teknologi informasi untuk dunia pendidikan, maka dapat menjawab ataupun mengatasi masalah yang sedang dihadapi pada era new normal ini dengan melakukan perbaikan kondisi pendidikan. Dunia pendidikan sangat diuntungkan dari kemajuan teknologi informasi karena bidang ini mendapatkan manfaat yang luar biasa. Mulai dari eksplorasi materi-materi pembelajaran yang sangat berkualitas yang bisa dengan mudah dilakukan serta tanpa mengalami sekat-sekat karena setiap orang dapat Banyak hal kreatif dan inovatif yang bisa dihadirkan untuk kelangsungan proses belajar mengajar pada pembelajaran terutama pembelajaran tatap muka di masa new normal. Dengan pemanfaatan teknologi sehingga diharapkan dapat membantu para guru, peserta didik untuk bisa sama-sama menikmati proses belajar mengajar yang lebih menarik dan menyenangkan.

\section{Media Video sebagai Sumber Belajar Digital}

Berkembangnya teknologi saat ini memberikan pengaruh bagi dunia pendidikan, khususnya dalam media pembelajaran yang digunakan dalam proses pembelajaran. Media pembelajaran adalah sarana yang memungkinkan terwujudnya hubungan langsung antara karya seorang pengembang mata pelajaran dengan siswa (Anderson dalam Melinda, 2017). Pemanfaatan pembelajaran dengan adanya sentuhan teknologi dapat mengubah paradigma pembelajaran, yang awalnya hanya menggunakan pembelajaran secara konvensional kemudian diinovasikan menjadi pembelajaran yang aktif, kreatif, menyenangkan (Astuti \& Iku, 2020). Peran guru dan perkembangan media pembelajaran, bagaimana perubahan peran guru sesuai dengan kemajuan dan perkembangan media pembelajaran (Sanjaya, 2012: 115-117) dalam (Amanullah $2020: 43$ ).

Guru sebagai pengembang media. Dengan semestinya guru merubah perannya dari guru sebagai sumber belajar dengan menggunakan bahasa verbal sebagai media, menjadi guru sebagai perancang dan pengembang sumber belajar yang dapat dimanfaatkan oleh setiap siswa kapan dan dimana saja. Guru sebagai pengelola pembelajaran. Dalam kepesatan perkembangan media dan sumber belajar, mestinya guru tidak lagi menempatkan diri sebagai satu-satunya sumber belajar yang menganggap dirinya yang serba tahu, akan tetapi orang yang dapat menunjukkan berbagai sumber belajar yang dapat digunakan peserta didik dalam proses pembelajarannya. Guru sebagai administrator dan fasilitator. Sebagai administrator berarti juga guru berperan sebagai organisator. Artinya dalam proses pembelajaran guru harus lebih banyak berperan dan bertanggung jawab dalam mengorganisasikan pengelaman belajar. Sebagai fasilitator guru harus menempatkan diri sebagai orang yang memberikan petunjuk dalam memanfaatkan penggunaan secara teknis berbagai peralatan media dan sumber belajar agar siswa dapat belajar secara optimal. 
Guru sebagai direktur. Sebagai direktur guru berperan dan bertanggung jawab dalam mengarahkan apa yang harus dilakukan siswa untuk mempelajari bahan pelajaran tertentu. Guru sebagai evaluator. Sebagai evaluator guru berperan untuk menentukan tingkat keberhasilan siswa dalam menguasai kompetensi sesuai dengan tujuan pembelajaran.

Istilah video berasal dari kata vidi atau visum yang artinya melihat atau mempunyai daya penglihatan. Arsyad (2013) dalam (Yuanta,2020:93) mengemukakan bahwa pengajaran melalui audio visual adalah produksi dan penggunaan materi yang penyerapannya melalui pandangan dan pendengaran serta tidak seluruhnya tergantung kepada pemahaman kata atau simbol-simbol yang serupa. Video merupakan gambar yang bergerak dan disertai oleh suara. Media video merupakan salah satu jenis media audio visual dan dapat menggambarkan suatu objek yang bergerak dengan suara yang susuai dengan isi gambar tersebut. Peran video adalah sebagai penyaji informasi. Media sebagai alat bantu dalam proses belajar dan pembelajaran. Guru sadar bahwa tanpa bantuan media, maka materi pembelajaran sulit untuk dimengerti dan dipahami oleh siswa, terutama pembelajaran yang rumit dan kompleks.Berkembangnya teknologi munculah berbagai sumber belajar baru yang semakin canggih salah satunya adalah sumber belajar digital audio visual atau media video.

Dalam perkembangan tersebut menunjukkan bahwa sumber belajar mengikuti perkembangan teknologi dan ilmu pengetahuan. Pengajaran dengan menggunakan media video bercirikan sumber belajar digital. Jadi pembelajaran melalui video adalah produksi dan penggunaan materi yang penyerapannya melalui penglihatan dan pendengaran. Media video merupakan salah satu media yang dapat digunakan dalam pembelajaran menyimak. Media video ini dapat menambah minat siswa dalam bekajar karena dapat menyimak sekaligus melihat gambar. Kemempuan video dapat menyajikan informasi, memaparkan proses, menjelaskan konsep-konsep yang rumit, mengajarkan ketrampilan, menyingkat atau memperpanjang waktu dan dapat mempengaruhi sikap. Tujuan Penggunaan Media Video Tujuan dari pembelajaran menggunakan media video yaitu mencakup tujuan kognitif, afektif dan psikomotor. (Anderson, 1987) dalam (Amanullah $2020: 43$ ).

1. Tujuan Kognitif

a) Dapat mengembangkan kemampuan kognitif yang menyangkut kemempuan mengenal kembali dan kemampuan memberikan rangsangan berupa gerak dan sensasi

b) Dapat mempertunjukkan serangkaian gambar diam tanpa suara sebagaimana media foto dan film bingkai meskipun kurang ekonomis

c) Video dapat digunakan untuk menunjukkan contoh cara bersikap atau berbuat dalam suatu penampilan, khususnya menyangkut interaksi manusiawi.

2. Tujuan Afektif Dengan menggunakan efek dan teknik, video dapat memjadi media yang sangat baik dalam mempengaruhi sikap dan emosi.

3. Tujuan Psikomotor

a) Video merupakan media yang tepat untuk memperlihatkan contoh ketrampilan yang menyangkut gerak. Gerakan bisa diperlambat maupun dipercepat

b) Melaui media siswa langsung mendapat umpan balik secara visual terhadap kemampuan mereka sehingga mencobe ketrampilan yang menyangkut gerakan tadi. Manfaat Penggunaan Media Video

Manfaat penggunaan media video antara lain : (Prastowo 2012) dalam (Amanullah $2020: 43$ ).

1) Memberikan pengalaman yang terduga kepada peserta didik.

2) Memperlihatkan secara nyata sesuatu yang pada awalnya tidak mungkin bisa dilihat.

3) Menganalisis perubahan dalam periode waktu tertentu.

4) Memberikan pengalaman kepada peserta didik untuk merasakan suatu keadaan tertentu.

5) Menampilkan presentasi studi kasus tentang kehidupan sebenarnya yang dapat memicu diskusi peserta didik. 
Dengan adanya media video siswa dapat menyaksikan secara langsung suatu peristiwa yang berbahaya maupun peristiwa lampau yang tidak bisa dihadirkan di dalam kelas. Siswapun dapat memutar kembali media video sesuai kebutuhan dan keperluan mereka. Pembelajaran dengan media video menumbuhkan minat serta motivasi siswa untuk selalu memperhatikan pelajaran. Kelebihan Media Video Menurut Daryanto (2011) (Amanullah 2020 : 43).ada beberapa kelebihan dalam penggunaan media video, antara lain :

a) Video dapat menambah suatu dimensi baru di dalam pembelajaran, video menyajikan gambar bergerak kepada siswa disamping suara yang menyertainya.

b) Video dapat menampilkan suatu fenomena yang sulit untuk dilihat secara nyata.

\section{Pengembangan Sumber Belajar Pembelajaran tatap muka di Era New Normal}

(Pratowo, 2018:27) Sumber belajar adalah suatu sistem yang terdiri dari sekumpulan bahan atau situasi yang dirancang menfasilitasi proses belajar siswa. Tujuan pengembangan sumber belajar bertujuan untuk :

1) Menyediakan bahan ajar yang sesuai dengan tuntutan kurikulum dengan mempertimbangkan kebutuhan siswa, yakni bahan ajar yang sesuai dengan karakteristik dan setting atau lingkungan sosial siswa.

2) Membantu siswa dalam memperoleh alternative bahan ajar disamping buku - buku teks yang terkadang sulit diperoleh

3) Memudahkan guru dalam melaksanakan pembelajaran.

Perubahan perluasan akses teknologi yang sangat pesat menjadikan pendidik maupun peserta didik harus mengimbangi dan mengikuti. Pendidikan bertujuan menciptakan karakter seseorang, diharapkan agar mempunyai wawasan yang cukup luas agar tercapai segala yang diharapkan. Strategi sebuah pembelajaran didalam jaringan mempunyai tujuan dan manfaat didalam berkembangnya aspek teknologi, pada hal ini yakni strategi serta media pembelajaran berbasis teknologi. Pemanfaatan teknologi untuk memperluasan program belajar di dunia yang mendukung pada perkembangan pembelajaran yang digadang dapat memecahkan masalah dalam kekurangan waktu serta ruang dalam pembelajaran bagi para pendidik dan pebelajar terutama dalam zona pendidikan. Perubahan pada faktor belajar pada situasi tersebut dapat dilihat pada bagaimana seorang pebelajar mencari materi pembelajaran yang sangat mudah sekali di cari dimanapun dan kapanpun. Penggunaan faktor teknologi untuk mendapat materi pembelajaran dan program pembelajaran sangat mudah di akses melalui youtube, app pembelajaran dan pembelajaran layaknya google form, dll. Pembaruan perubahan dalam program suatu pembelajaran berpengaruh juga pada kualitas penggunanya.

Kebutuhan dalam mendukung perluasan pembelajaran di dunia mendukung perkembangan pembelajaran yang berkontribusi mengantisipasi keminimalisasi waktu serta ruang untuk penggunannya. Dampak yang ditimbulkan dari adanya perkembangan ini, yaitu adanya pola berfikir yang perlu diubah dan bagaimana pola fikir dapat dibentuk melalui berbagai macam perkembangan teknologi, hal-hal tersebut menjadi dasar bagaiamana pentingnya teknologi pada kehidupan manusia yang seutuhnya, anak-anak dalam pola pikir, atitude, tingkah laku dan sikap yang dipengaruhi teknologi akan menjadi berbeda ketika sebelum adanya teknologi yang berkembang seperti sekarang ini. Untuk memanfaatkan adanya perkembangan teknologi yang semakin berkembang guru perlu mengembangkan inovasi sumber belajar untuk meningkatkan mutu SDM guru itu sendiri. Pembelajaran dengan menyatukan segala macam metode model dan strategi pembelajaran yang memakai media teknologi digital yang diupayakan dapat mendukung bukan hanya pada saat proses belajar dan pembelajaran tatap muka, akan lebih baik apabila kegiatan di zona tatap antar muka, baik terjadi di zona pembelajaran intenal, di lingkugan keluarga, ataupun pada zona lain dengan koneksi jaringan yang mumpuni di era new normal. Implementasi dari pengembangan inovasi sumber belajar melalui media teknologi digital memberi ruang dan waktu belajar pesera didik menjadi lebih baik, mempermudah serta mempercepat proses komunikasi antara pendidik dengan siswa. 
Teknologi yang berupa online dan offline adalah proses pembelajaran yang menggabungkan antara media teknologi digital sesuai dengan perkembangannya. Berkaitan dengan pembelajaran di era new normal seperti ini menjadi bentuk persoalan. Bagaimana mengembangkan inovasi sumber belajar di era new normal auntuk dapat meningkatkan kemampuan siswa dalam segala aspek kognitif maupun psikomotor yang menyedikan kemudahan dalam proses pembelajaran dan tentunya adanya tatap muka yang dapat menambah waktu belajar pebelajar, mempermudah serta mempercepat sebuah proses komunikasi antara pendidik dengan pebelajar. Pengembangkan inovasi Sumber Belajar sendiri diperuntukkan sebagai proses memfasilitasi belajar untuk para pembelajar. Pada proses dalam hal tersebut dilaksanakan kontribusi dari berbagai media digital materi pembelajaran yang dimana nantinya akan digunakan sebagai bahan ajar yang dirasa sesuai dengan ketersediaan teknologi yang mampu menyampaikan suatu informasi bahan ajar pembelajaran. Pada era new normal ini para pendidik dapat memaksimalkan ketercapaian proses pembelajarannya, sehingga peseerta didik mampu mengembangkan soft skill di dalam manfaat media teknologi digital dalam proses pembelajaran. Digital merujuk pada gabungan elemen perangkat keras (pemrosesan, memori, input, dan komunikasi) dan perangkat lunak (sistem operasi dan program aplikasi) untuk melakukan berbagai tugas. Dengan demikian sumber belajar digital dapat dipahami sebagai gabungan elemen perangkat keras dan perangkat lunak yang mempunyai potensi untuk mengatasi masalah belajar dan memfasilitasi kegiatan belajar (Christina, 2016)

\section{METODE PENELITIAN}

Teknis analisis data yang digunakan merupakan tipe deskriptif analisis survey. Menurut Sugiyono (2015:53) pengertian deskriptif adalah : "Penelitian deskriptif adalah penelitian yang dilakukan untuk mengetahui keberadaan variabel mandiri, baik hanya pada satu variabel atau lebih tanpa membuat perbandingan atau menghubungkan dengan variabel lainnya (variabel mandiri adalah variabel yang berdiri sendiri, bukan variabel independen, karena kalau variabel independen selalu dipasangkan dengan variabel dependen". Dengan metode ini dimaksudkan untuk mengumpulkan data historis dan mengamati secara saksama mengenai aspek-aspek tertentu yang berkaitan dengan masalah yang sedang diteliti sehingga akan memperoleh data-data yang dapat mendukung penyusunan laporan analisis. Analisis ini melibatkan seluruh populasi (Nonprobability Sampling). Jumlah populasi dalam penelitian ini adalah 61 Guru dan 32 siswa kelas 8.1 siswa SMPN 2 Rantepao. Menurut Sugiyono (2017) "Sampling jenuh adalah teknik penentuan sampel bila semua anggota populasi digunakan sebagai sampel. Istilah lain sampel jenuh adalah sensus, dimana semua anggota populasi dijadikan sampel. Dalam penelitian ini teknik pengukuran dilakukan dengan menghitung nilai Tingkat Capaian Responden (TCR) masing-masing kategori dari data deskriptif variabel. Rumus yang digunakan yaitu :

Keterangan :

TCR $=$ Tingkat Capaian Responden

Rs $\quad=$ Rata-rata skor jawaban responden

$\mathrm{n} \quad=$ Nilai Skor Jawaban Kriteria Interpretasi skor untuk Tingkat Capaian Responden (TCR) adalah sebagai berikut.

$$
\mathrm{TCR}=\frac{R s}{n} \mathrm{X} 100 \%
$$

Tabel 1. Kriteria Skala TCR

\begin{tabular}{ccc}
\hline No & Angka & Keterangan \\
\hline 1 & $00 \%-54 \%$ & Tidak Baik \\
\hline 2 & $55 \%-64 \%$ & Kurang Baik \\
\hline 3 & $65 \%-79 \%$ & Cukup Baik \\
\hline 4 & $80 \%-89 \%$ & Baik \\
\hline 5 & $90 \%-100 \%$ & Sangat Baik \\
\hline
\end{tabular}


Data-data yang diperoleh tersebut kemudian diproses dan dianalis lebih lanjut dengan dasar teori yang telah dipelajari sehingga memperoleh gambaran mengenai objek tersebut dan dapat ditarik kesimpulan mengenai masalah yang dianalisis.

\section{HASIL DAN PEMBAHASAN}

Era revolusi 4.0 menjadi sebuah era perkembangan teknologi di berbagai lini, salah satunya pada dunia pendidikan yang kini di era new normal kembali dilaksanakan pembelajaran secaraaa tatap muka. Saat ini banyak melakukan transformasi pemanfaatan teknologi sebagai salah sumber belajar melalui satu media pembelajaran guru kelas (Arif dkk, 2020) Maka, harus siap menghadapi tantangan terbesarnya yaitu tentang peningkatan kompetensi di era teknologi untuk meningkatkan mutu SDM sebagai guru. Untuk mengetahui hasil analisis tentang Presentase TCR Mutu SDM Guru SMPN 2 Rantepao melalui Pemanfaatan Teknologi menggambarkan presentase mutu SDM SMPN 2 Rantepao dengan guru sebagai responden variable analisis.

Tabel 2. Presentase TCR Mutu SDM Guru SMPN 2 Rantepao melalui Pemanfaatan Teknologi

\begin{tabular}{clccc}
\hline No & \multicolumn{1}{c}{ Indikator } & Mean & TCR(\%) & Keterangan \\
\hline 1 & Sebagai Sumber Informasi & 3,67 & 73,44 & Cukup Baik \\
\hline 2 & Sebagai Sumber Belajar & 3,72 & 74,42 & Cukup Baik \\
\hline 3 & Sebagai Media Pembelajaran & 3,19 & 63,93 & Kurang \\
\hline 4 & Sebagai Alat Evaluasi Hasil Belajar & 3,60 & 72,13 & Cukup Baik \\
\hline
\end{tabular}

Berdasarkan Tabel 2 dapat dijelaskan bahwa Mutu SDM Guru SMPN 2 Rantepao melalui Pemanfaatan Teknologi cukup baik dalam memanfaatkan teknologi sebagai sumber informasi, sumber belajar dan sebagai alat evaluasi hasil belajar dengan rata-rata indikator masing - masing yaitu 3,67, 3,72 dan 3,60 dan persentase TCR masing - masing adalah 73,44\%, 74,42 dan 72,13. Walaupun masih kurang baik dalam memanfaatkan teknologi sebagai media pembelajaran yang terlihat dari rata-rata indikator 3,19 dan persentase TCR sebesar 63,93\%. Hasil analisis guru guru SMPN 2 Rantepao sudah cukup baik dalam memanfaatkan teknologi sebagai sumber belajar dengan rata-rata 3,72 dan persentase TCR sebesar 74,42\%.

Hal ini mengindikasikan bahwa guru - guru SMPN 2 Rantepao perlu meningkatkan mutu SDM melalui pemanfaatan teknologi sebagai media pembelajaran untuk mendukung pengembangan sumber belajar digital media video untuk memudahkan guru dalam melaksanakan pembelajaran tatap muka di era new normal. Hal ini sesuai dengan apa yang terjadi saat sekarang ini, faktanya bahwa guru sebagai SDM yang berkualitas di era digital harus melek teknologi. Untuk mengetahui hasil analisis tentang Pengembangan Sumber Belajar Digital Media Video Guru SMPN 2 Rantepao, maka dari pengolahan data dilakukan deskripsi dengan tujuan menggambarkan propersi jawaban guru sebagai responden terhadap variabel analisis.

Tabel 3. Frekuensi Pengembangan Sumber Belajar Digital Media Video Guru SMPN 2 Rantepao

\begin{tabular}{clcccc}
\hline No & \multicolumn{1}{c}{ Indikator } & Mean & TCR(\%) & Keterangan \\
\hline 1 & $\begin{array}{l}\text { Memanfaatkan media video sebagai sumber belajar } \\
\text { digital sesuai tuntutan kurikulum. }\end{array}$ & 35 & 71,15 & Cukup Baik \\
\hline 2 & $\begin{array}{l}\text { Merancang sumber belajar digital media video untuk } \\
\text { memudahkan guru dalam melaksanakan } \\
\text { pembelajaran }\end{array}$ & & 63,60 & Kurang Baik \\
\hline 3 & $\begin{array}{l}\text { Menggunakan sumber belajar digital media video } \\
\text { sebagai alternatif bahan ajar dalam proses } \\
\text { pembelajaran. }\end{array}$
\end{tabular}


Berdasarkan Tabel 3 dapat dijelaskan bahwa Pengembangan Sumber Belajar Digital Media Video Guru SMPN 2 Rantepao cukup baik dalam memanfaatkan media video sebagai sumber belajar digital sesuai tuntutan kurikulum dengan rata-rata indikator sebesar 3,55 dan TCR 71,15\%. Guru guru SMPN 2 Rantepao juga sudah cukup baik dalam menggunakan sumber belajar digital media video sebagai alternatif bahan ajar dalam proses pembelajaran dengan rata-rata 3,54 dan TCR 75,30\%. Walaupun untuk merancang sumber belajar digital media video untuk memudahkan guru dalam melaksanakan pembelajaran masih kurang baik yang terlihat dari rata-rata indikator 3,18 dan TCR 63,60\%. Hasil analisis guru - guru SMPN 2 Rantepao sudah cukup baik dalam menggunakan sumber belajar digital media video sebagai alternatif bahan ajar dalam proses pembelajaran dengan rata-rata 3,54 dan TCR 75,30\%.

Hal ini mengindikasikan bahwa guru - guru SMPN 2 Rantepao perlu meningkatkan kreativitas dan inovasi untuk meningkatkan mutu sebagai SDM dalam pengembangan sumber belajar digital media video agar dapat merancang sumber belajar untuk memudahkan guru dalam melaksanakan pembelajaran tatap muka di era new normal. Dengan demikian (Yudianto,2017 : 234) pengembangan sumber belajar digital media video dapat membantu peserta didik yang lemah dan lambat menangkap suatu pesan menjadi mudah dalam menerima dan memahami inovasi yang disampaikan, hal ini disebabkan karena video mampu mengkombinasikan antara visual (gambar) dengan audio (suara). Untuk mengetahui hasil analisis tentang frekuensi penggunaan sumber belajar digital media video kelas VIII.1 SMPN 2 rantepao dengan siswa sebagai responden variable analisis.

Tabel 4. Frekuensi Penggunaan Sumber Belajar Digital Media Video Kelas VIII.1 SMPN 2 Rantepao

\begin{tabular}{clccc}
\hline No & \multicolumn{1}{c}{ Indikator } & Mean & TCR(\%) & Keterangan \\
\hline 1 & $\begin{array}{l}\text { Sumber belajar digital media video memberikan } \\
\text { motivasi belajar kepada siswa. }\end{array}$ & 3,97 & 79,37 & Cukup Baik \\
\hline 2 & $\begin{array}{l}\text { Sumber belajar digital media video mewujudkan } \\
\text { situasi belajar efektif kepada siswa. }\end{array}$ & 4,13 & 82,25 & Baik \\
\hline 3 & $\begin{array}{l}\text { Sumber belajar digital media video menciptakan } \\
\text { suasana belajar yang tidak mudah dilupakan oleh } \\
\text { siswa }\end{array}$ & 4,06 & 81,25 & Baik \\
\hline
\end{tabular}

Berdasarkan tabel 4 Frekuensi Penggunaan Sumber Belajar Digital Media Video Kelas VIII.1 SMPN 2 Rantepao menunjukkan bahwa Sumber belajar digital media video cukup tinggi memberikan motivasi belajar kepada siswa dengan rata - rata indicator 3,97 dan TCR 79,37 \%, tinggi dalam mewujudkan situasi belajar efektif dan menciptakan suasana belajar yang tidak mudah dilupakan siswa dengan rata - rata indicator 4,13 dan 4,06 dan TCR 82,25 \% dan 81,25 \%. Hasil analisis siswa kelas VIII.1 SMPN 2 Rantepao menunjukkan bahwa ternyata Penggunaan Sumber Belajar Digital Media Video tinggi dalam mewujudkan situasi belajar efektif kepada siswa dengan rata - rata indicator 4,13 dan TCR 82,25\% pada pembelajaran tatap muka di era new normal. Hal ini mengindikasikan Pengembangan Sumber Belajar Digital Media Video memberikan dampak pada peningkatan mutu SDM guru dalam pembelajaran bagi siswa di SMPN 2 Rantepao. Dapat diartikan bahwa tinggi rendahnya Penggunaan Sumber Belajar Digital Media Video akan menentukan tinggi rendahnya mutu SDM guru serta kualitas belajar siswa. Semakin tinggi sumber belajar digital maka akan semakin tinggi pula perkembangan siswa tersebut, begitu pun sebaliknya rendah sumber belajar digital maka akan semakin rendah pula mutu SDM guru dan kualitas belajar siswa.

\section{KESIMPULAN}

Kesimpulan

Berdasarkan hasil analisis dari pembahasan pengembangan sumber belajar digital media video untuk meningkatkan mutu SDM Guru melalui pemanfaatan teknologi pada pembelajaran tatap muka di era new normal dapat disimpulkan bahwa pengembangan sumber belajar digital media video dapat dikatakan cukup baik untuk meningkatkan mutu SDM guru serta kualitas belajar 
siswa.Oleh karena itu, sumber belajar digital media video perlu dikembangkan dengan inovasi dalam pembelajaran, mutlak diperlukan untuk memenuhi kebutuhan siswa guna mempermudah memahami materi lewat media pembelajaran kreatif, inovatif dan informative. Dengan demikian siswa dapat memaksimalkan pembelajarannya di kelas melalui media yang disajikan oleh guru di dalam kelas untuk membantu proses belajar mengajar. Dengan adanya media video, maka, peserta didik akan lebih paham dengan materi yang disampaikan oleh guru melalui unsur-unsur yang terdapat dalam media video seperti suara, teks, animasi, dan grafik sehingga peserta didik mampu mencapai kemampuan baik dalam ranah kognitif, afektif maupun psikomotorik. Kegiatan ini juga dapat digunakan sebagai sarana bagai guru mengembangkan diri dan keterampilan dengan memanfaatkan teknologi untuk meningkatkan SDM guru yang berkualitas dalam pembelajaran tatap muka di era new normal.

Implikasi

Implikasi hasil penelitian ini secara teoritis adalah sebagai teori atau menggunakan konsep dalam media video pembelajaran memanfaatkan teknologi oleh gutu. secara praktis, implikasi dari hasil penelitian ini menjadi acuan bagi pengembangan guru dalam kemampuan menggunakan dan memanfaatkan teknologi sebagai sumber belajar digital media video untuk meningkatkan mutu SDM Guru.

Saran

Pelatihan pemanfaatan teknologi secara garis besar akan memberikan wawasan dalam pengembangan sumber belajar digital media video media dalam pembelajaran tatap muka di era new normal agar lebih berinovasi serta kreatif dalam proses pembelajaran, sehingga siswa lebih aktif dan bersemangat dalam menjalani proses belajar Model dan metode yang ditawarkan media teknologi digital, bertema pendidikan maupun yang dikemas melalui inovasi multimedia disarankan dapat meningkatkan keefektifan pembelajaran tatap muka di era new normal yang bertujuan untuk memudahkan siswa dan guru dalam proses pembelajaran. Keuntungan yang didapat oleh siswa, mereka tidak perlu membawa buku yang banyak dan dan tebal untuk mempelajari suatu materi. Keuntungan yang didapatkan oleh guru adalah untuk meningkatkan mutu SDM sehingga guru tidak selalu menjadi patokan untuk sumber belajar, serta guru juga dapat meningkatkan keinovatifan dalam menyampaikan konten materi pada siswa.

\section{DAFTAR PUSTAKA}

1. Adam D. (2020). "The simulations driving the world's response to COVID - 19". Diunduh pada tanggal 1/06/2021 jam 20.13 Wita dari https://www.nature.com/articles/d41586-02001003-6.

2. Amanullah, M. A. (2020). Pengembangan Media Pembelajaran Flipbook Digital Guna Menunjang Proses Pembelajaran Di Era Revolusi Industri 4.0. Jurnal Dimensi Pendidikan dan Pembelajaran, 8(1), 37-44.

3. Anriani, N., Hidayat, S., \& Setiani, Y. (2020). DIGITALISASI PEMBELAJARAN DI ERA NEW NORMAL. In Prosiding Seminar Nasional Pendidikan FKIP (Vol. 3, No. 1, pp. 390-393).

4. Arif, D. S. F., Zaenuri, Z., \& Cahyono, A. N. (2020). Analisis Kemampuan Berpikir Kritis Matematis Pada Model Problem Based Learning (PBL) Berbantu Media Pembelajaran Interaktif dan Google Classroom. In Prosiding Seminar Nasional Pascasarjana (PROSNAMPAS) (Vol. 3, No. 1, pp. 323-328).

5. Aspiyana, T., \& Rianit, R. (2020). STRATEGI PENDIDIKAN DALAM MENINGKATKAN KUALITAS PENDIDIKAN DI ERA NEW NORMAL. Satya Sastraharing, 4(2), 61-71.

6. Astuti, N., \& Iku, P. F. (2020). Pembelajaran Multiliterasi sebagai Wahana Peningkatan Keterampilan Belajar Siswa Di Masa Pandemi Covid 19. Aliterasi: Jurnal Pendidikan Bahasa dan sastra Indonesia, 1(1), 12-18.

7. Bahri, S., \& Arafah, N. (2020). Analisis Manajemen Sdm Dalam Mengembangkan Strategi Pembelajaran Di Era New Normal. Tafkir: Interdisciplinary Journal of Islamic Education, 1(1), $20-40$. 
8. Chritina, F. d. (2016). Persepsi Guru Tentang Digital Natives, Sumber Belajar Digital dan Motivasi Memanfaatkan Sumber Belajar Digital. Jurnal Inovasi Teknologi Pendidikan, 13-24.

9. Fanny, A. M. (2020). Teknologi Informasi dan Komunikasi Pada Pendidikan Dasar:"Tinjauan Kritis dan Implikasinya". Didaktis: Jurnal Pendidikan dan Ilmu Pengetahuan, 20(1).

10. Khairi, A., \& Danil, M. (2015). KEMAMPUAN PEMBELAJARAN BERBASIS TIK PADA GURU SMP DI KOTA PADANG DALAM MENYAMBUT IMPELEMENTASI KURIKULUM 2013. Jurnal ipteks terapan, 8(4), 131-145.

11. Lamambar, A. (2021). PEMANFAATAN TEKNOLOGI INFORMASI DAN KOMUNIKASI DALAM PEMBELAJARAN DI ERA NEW NORMAL KELAS IV SEKOLAH DASAR NEGERI 182/I HUTAN LINDUNG (Doctoral dissertation, Universitas Jambi).

12. Maemunah, M., Munir, M., Salamah, U., Saputro, A. N. C., Arlis, A., Purandina, I. P. Y., ... \& Jamaludin, J. (2021). Pendidikan Era New Normal.Malang : CV. Pustaka Learning Center

13. Melinda, Vannisa Aviana, dkk. (2017). Pengembangan Media Video Pembelajaran IPS Berbasis Virtual Field Trip (VFT) Pada Kelas V SDNU Kraton-Kencong. JINOTEP, Volume 3, Nomor 2, April 2017.

14. Mukarromah, L., \& Siskawati, F. S. (2020). PENGEMBANGAN GAME EDUKASI "HOTSNAKER" BERBANTUAN VLOG SEBAGAI ALTERNATIF MEDIA PEMBELAJARAN MATEMATIKA DI ERA NEW NORMAL. In Urban Green Conference Proceeding Library (Vol. 1, pp. 40-44).

15. Nasrika, N. (2019). Pengembangan Sumber Daya Manusia Pada Era Globalisasi. Revitalisasi Manajemen Pendidikan Anak Usia Dini (Paud) Di Era Revolusi Industri 4.0.

16. Nurhayati, N., \& Zuhra, F. (2020). ANALISIS TINGKAT KEPUASAN MAHASISWA FKIP MATEMATIKA UNIVERSITAS ALMUSLIM TERHADAP PEMANFAATAN E-LEARNING DI ERA PANDEMI COVID 19. Jurnal Ilmiah Pendidikan Matematika Al Qalasadi, 4(2), 83-90.

17. Ozkeser, B. (2019). Impact of training on employee motivation in human resources management. Procedia Computer Science, 158, 802-810.

18. PANDUAN PENYELENGGARAAAN PEMBELAJARAN PADA TAHUN AJARAN 2020/2021 DAN TAHUN AKADEMIK 2020/2021 DIMASA PANDEMI CORONAVIRUS DISEASE 2019 (COVID-19). Keputusan Bersama 4 Mentri. Mentri Pendidikan dan Kebudayaan, Mentri Agama, Mentri Kesehatan dan Mentri Dalam Negeri.

19. Pratowo, Andi.(2018).Sumber Belajar \& Pusat Sumber Belajar.Depok : Prenada Group.

20. Putria, H., Maula, L. H., \&Uswatun, D. A. 2020. Analisis Proses Pembelajaran dalam Jaringan (DARING) Masa Pandemi Covid- 19 Pada Guru Sekolah Dasar. Jurnal Basicedu, 4(4).

21. Haji, Son. (2019, March). Problematika Sumber Daya Manusia (SDM) di Sekolah Dasar yang Terletak di Daerah Terpencil. In PROSIDING SEMINAR NASIONAL PROGRAM PASCASARJANA UNIVERSITAS PGRI PALEMBANG (Vol. 12, No. 01).

22. Henry Simamora edisi III. (2015). Manajemen Sumber Daya Manusia.Penerbit STIE YKPN

23. Rahman, F. A., \& Bhakti, C. P. (2020, September). Implementasi Eksplorasi Karier Siswa di Era New Normal. In Prosiding Seminar Bimbingan dan Konseling (pp. 36-42).

24. Setiana, D. J. (2018). Manajemen dan Supervisi Pendidikan. Bandung: CV Pustaka Setia.

25. Sugiyono.(2015). Metode Penelitian Pendidikan (Pendekatan Kuantitatif, Kualitatif dan R\&D. Bandung: Alfabeta

26. Sugiyono.(2017).Metode Penelitian Kuantitatif, kualitatif, dan Kombinasi (Mixed Methods). Bandung. Alfabeta.

27. Suprijono, A.,dkk.(2020). Kesiapan Dunia Pendidikan Menghadapi Era New Normal. Pare - Pare : IAIN Pare - Pare Nusantara Press.

28. Yuanta, F. (2020). Pengembangan Media Video Pembelajaran Ilmu Pengetahuan Sosial pada Siswa Sekolah Dasar. Trapsila: Jurnal Pendidikan Dasar, 1(02), 91-100.

29. Yudianto, Arif (2017) PENERAPAN VIDEO SEBAGAI MEDIA PEMBELAJARAN. In: Seminar Nasional Pendidikan 2017.

30. Yuwono, T., Purwanto, A., Fayzhall, M., Goestjahjanti, F. S., Winanti, W.,... \& Yani, A. (2020). Peran Kepemimpinan Transformasional dan Organisasi Pembelajaran terhadap Kapasitas Inovasi Sekolah. EduPsyCouns: Journal of Education, Psychology and Counseling, 2(1), 122-145.

31. Zuraini, Z., \& Nurhayati, N. (2021). Efektifitas Pembelajaran E-Learning Diera New Normal. Genta Mulia: Jurnal Ilmiah Pendidikan, 12(1). 